\title{
Improving the investment potential management system of a construction company
}

\author{
Elena Zubeeva ${ }^{1, *}$, Natalia Mezina ${ }^{1}$, Alexander Matusevich ${ }^{2}$, and Igor Merzlikin ${ }^{3}$ \\ ${ }^{1}$ Moscow Aviation Institute, Volokolamskoe highway, 4, Moscow, 125993, Russia \\ ${ }^{2}$ Moscow State University of Civil Engineering, 26, Yaroslavskoe shosse, Moscow, 129337, Russia \\ ${ }^{3}$ Moscow State Technical University of Civil Aviation, 20 Kronshtadtsky blvd, Moscow, 125993, \\ Russia
}

\begin{abstract}
The purpose of this paper is to improve the methodological provisions for managing the development of the investment potential of a construction company. As a result of the study, the characteristics of the main components of the investment potential of a construction company were determined, factors influencing its condition were identified and systematized. The key indicators and elements used in the study, including objectives, resources, abilities, opportunities and results, allow characterizing private potentials and provide maximum accuracy and reliability of the assessment. On this basis, a system for assessing the state, forecasting and managing the development of the investment potential of a construction company has been developed.
\end{abstract}

\section{Introduction}

After analyzing the state of the construction market in a separate region using the tools of the theory of industrial organization, it was found that the construction market is conditionally divided into two approximately equal groups. The first group includes the 10 largest companies, occupies $50 \%$ of the construction market and receives $90 \%$ of the industry profit. The second group includes the rest of the companies and occupies the same $50 \%$ of the industry market, but receives only $10 \%$ of the profit $[1,2]$. In this regard, in the market of imperfect competition, construction companies have to combine in their activities the functions of various participants in the regional investment and construction cluster (hereinafter ICC), which leads to the need to ensure their competitiveness through the development of internal potentialities, including investment ones.

\section{Materials and Methods}

Table 1 shows a system of identification signs of a construction cluster, supplemented by a sign that determines the possibility of developing investment potential (hereinafter IP) of participants in a regional ICC.

\footnotetext{
* Corresponding author: helen400@yandex.ru
} 
Table 1. Cluster system of the regional ICC

\begin{tabular}{|l|l|l|l|}
\hline $\begin{array}{c}\text { Identification } \\
\text { signs }\end{array}$ & $\begin{array}{l}\text { Investment and functional } \\
\text { cluster }\end{array}$ & \multicolumn{1}{|c|}{ Management cluster } & \multicolumn{1}{c|}{ Production cluster } \\
\hline Definition & $\begin{array}{l}\text { a group of entities focused } \\
\text { on the process of investing } \\
\text { in an object under } \\
\text { construction } \\
\text { (reconstruction) }\end{array}$ & $\begin{array}{l}\text { a group of entities focused } \\
\text { on solving problems of } \\
\text { managing the investment } \\
\text { and construction process }\end{array}$ & $\begin{array}{l}\text { a group of entities directly } \\
\text { implementing the process } \\
\text { of construction } \\
\text { (reconstruction) of an } \\
\text { object }\end{array}$ \\
\hline Cluster leader & Investor & Client & General Contractor \\
\hline Leader function & $\begin{array}{l}\text { makes investments in the } \\
\text { object and bears the basic } \\
\text { market risks due to the } \\
\text { functionality of the object, } \\
\text { the purpose of its } \\
\text { construction } \\
\text { (reconstruction) and } \\
\text { operation }\end{array}$ & $\begin{array}{l}\text { acts as a representative of } \\
\text { the investor and is } \\
\text { responsible for the } \\
\text { organization and } \\
\text { management of the entire } \\
\text { investment and construction } \\
\text { project }\end{array}$ & $\begin{array}{l}\text { is responsible for the } \\
\text { construction } \\
\text { (reconstruction) process, } \\
\text { bears the technical, } \\
\text { technological and } \\
\text { economic risks of the } \\
\text { production process }\end{array}$ \\
\hline $\begin{array}{l}\text { IP development } \\
\text { opportunities }\end{array}$ & $\begin{array}{l}\text { enables the subjects of ICC } \\
\text { to implement IP through } \\
\text { participation in an } \\
\text { investment and construction } \\
\text { project }\end{array}$ & $\begin{array}{l}\text { selects participants in an } \\
\text { investment and construction } \\
\text { project, focusing on the } \\
\text { existing IP }\end{array}$ & $\begin{array}{l}\text { gets the opportunity to } \\
\text { develop IP based on the use } \\
\text { of available resources in } \\
\text { the process of project } \\
\text { implementation }\end{array}$ \\
\hline
\end{tabular}

Investment potential of a construction company is considered as an integral part of its economic potential, which is the real ability of an economic entity to ensure its long-term functioning and achievement of strategic objectives, taking into account the combined capabilities of the internal and external environment through the use of the system of available resources.

In other words, IP is an organic combination of resources at the disposal of a construction company, the company's ability to achieve certain goals based on the rational use of available resources, the company's ability to maximally satisfy the needs for goods and services in order to implement an investment project [3].

Structurally, IP is represented by a set of private potentials, among which one can single out: production, financial, intellectual, innovative, informational, reputational, marketing, social and other private potentials.

For the purposes of our study, we will consider the production, financial, intellectual and innovative components of IP of a construction company [4].

The production potential of a company is determined by the availability of material resources and the possibilities of their effective use; financial one - by the availability of financial resources and the company's ability to structure them into special purpose funds intended for investment activities; intellectual one - the availability of intellectual resources and the ability to use them through the application of knowledge and work skills of the personnel; innovative one - the availability and possibilities of using information resources in order to implement an investment and construction project [5].

Summing up the characteristics of the potentials that form IP of the construction company, it seems appropriate to characterize the main components of IP of the construction company in the system "tasks-resources-abilities-opportunities-results" (Table 2).

Research and presentation of IP in the system "tasks-resources-abilities-opportunitiesresults" provides an opportunity for effective management of its development. 
Table 2. Characteristics of the potentials of a construction company in the system "tasksresources-abilities-opportunities-results"

\begin{tabular}{|c|c|c|c|c|}
\hline & $\begin{array}{c}\text { Production } \\
\text { potential }\end{array}$ & $\begin{array}{l}\text { Financial } \\
\text { potential }\end{array}$ & Intellectual potential & $\begin{array}{c}\text { Innovative } \\
\text { potential }\end{array}$ \\
\hline $\begin{array}{l}\text { System of } \\
\text { strategic } \\
\text { objectives }\end{array}$ & $\begin{array}{l}\text { formation and } \\
\text { maintenance of a } \\
\text { balanced structure } \\
\text { of all components } \\
\text { of production } \\
\text { potential }\end{array}$ & $\begin{array}{l}\text { optimization of } \\
\text { financial flows }\end{array}$ & $\begin{array}{l}\text { provision of all areas } \\
\text { of the construction } \\
\text { company with highly } \\
\text { qualified workers }\end{array}$ & $\begin{array}{l}\text { transition of a } \\
\text { company from one } \\
\text { state to another, } \\
\text { much higher, } \\
\text { necessary to } \\
\text { achieve the goals }\end{array}$ \\
\hline $\begin{array}{l}\text { Cash } \\
\text { resource } \\
\text { system }\end{array}$ & $\begin{array}{l}\text { set of inventories } \\
\text { and fixed assets }\end{array}$ & $\begin{array}{l}\text { cash income, } \\
\text { savings and } \\
\text { receipts at the } \\
\text { disposal of an } \\
\text { economic entity }\end{array}$ & $\begin{array}{l}\text { the total number of } \\
\text { personnel working in a } \\
\text { construction company, } \\
\text { managers, specialists, } \\
\text { workers, maintenance } \\
\text { personnel, etc. }\end{array}$ & intangible assets \\
\hline $\begin{array}{l}\text { Owning a set } \\
\text { of abilities }\end{array}$ & $\begin{array}{l}\text { technical, } \\
\text { qualitative and } \\
\text { other properties of } \\
\text { machines, } \\
\text { equipment, } \\
\text { materials, on which } \\
\text { the quality and } \\
\text { quantity of } \\
\text { products } \\
\text { manufactured, } \\
\text { works and services } \\
\text { provided directly } \\
\text { depend }\end{array}$ & $\begin{array}{l}\text { the ability to } \\
\text { promptly form, } \\
\text { direct and } \\
\text { accumulate } \\
\text { financial flows, as } \\
\text { well as the ability } \\
\text { to accelerate the } \\
\text { development of } \\
\text { investments, a } \\
\text { sharp increase in } \\
\text { the capital value of } \\
\text { a business and a } \\
\text { quick capital } \\
\text { turnover }\end{array}$ & $\begin{array}{l}\text { a set of abilities, } \\
\text { professional skills of } \\
\text { the company's } \\
\text { employees, necessary } \\
\text { for them to fulfill their } \\
\text { professional duties, as } \\
\text { well as the ability to } \\
\text { formulate and solve } \\
\text { new creative tasks, } \\
\text { create something } \\
\text { qualitatively new, } \\
\text { distinguished by its } \\
\text { originality and } \\
\text { uniqueness }\end{array}$ & $\begin{array}{l}\text { subjective } \\
\text { conditions for the } \\
\text { use and } \\
\text { transformation of } \\
\text { the company's } \\
\text { resources in all } \\
\text { types of innovative } \\
\text { activities }\end{array}$ \\
\hline $\begin{array}{l}\text { Real } \\
\text { opportunities }\end{array}$ & $\begin{array}{l}\text { objective } \\
\text { conditions for } \\
\text { attracting and using } \\
\text { fixed assets and } \\
\text { inventories }\end{array}$ & $\begin{array}{l}\text { features of } \\
\text { financial, } \\
\text { accounting and } \\
\text { investment } \\
\text { policies, financial } \\
\text { strategy, } \\
\text { refinancing rate, } \\
\text { etc. }\end{array}$ & $\begin{array}{l}\text { a set of conditions of } \\
\text { the external and } \\
\text { internal environment } \\
\text { of a company that } \\
\text { allow improving and } \\
\text { developing the skills } \\
\text { and abilities of } \\
\text { personnel: } \\
\text { organizational culture, } \\
\text { personnel policy, } \\
\text { motivation system, etc. }\end{array}$ & $\begin{array}{l}\text { objective } \\
\text { conditions for } \\
\text { attracting resources } \\
\text { and realizing } \\
\text { abilities in } \\
\text { scientific, scientific } \\
\text { and technical, } \\
\text { production and } \\
\text { commercial } \\
\text { activities }\end{array}$ \\
\hline $\begin{array}{l}\text { Results as a } \\
\text { reflection of } \\
\text { the system of } \\
\text { strategic } \\
\text { objectives }\end{array}$ & $\begin{array}{l}\text { implementation of } \\
\text { the production } \\
\text { program }\end{array}$ & $\begin{array}{l}\text { maximizing } \\
\text { positive financial } \\
\text { results }\end{array}$ & $\begin{array}{l}\text { creation of a team } \\
\text { capable of changes, } \\
\text { development, renewal }\end{array}$ & $\begin{array}{l}\text { reaching companies } \\
\text { of a higher level of } \\
\text { development }\end{array}$ \\
\hline
\end{tabular}

\section{Results}

The study of the theoretical foundations of the formation and functioning of IP of the companies of the regional ICC made it possible to identify and bring into a certain system the factors that affect its state. Previously existing systematizations were based on the identification of the following classification features: formation environment (internal and external), features of construction as a type of activity. From the point of view of achieving the goals of our study, it seems necessary and expedient to introduce into the system one more classification feature, namely, the feature of the objectivity of the emergence of the action of an individual factor or their group.

It is proposed to distribute the factors into the following groups: objectively acting factors, i.e. the degree of influence of the management entities on them is almost equal to 
zero; objective-subjective - these are factors, the reasons for which do not depend on the management entities at the level of the construction company, however, these entities have the opportunity to reduce the strength of the influence of this factor by making a specific management decision; subjective factors, namely, those factors whose action directly depends on the person making the managerial decision [6,7].

The process of managing the development of IP of a construction company is presented by the author in a formalized form. The calculation of the integral indicator of IP of a construction company is made according to the formula:

$$
I_{t}=\sum_{i=1}^{n} \lambda_{i} \delta_{i t}=\left(\lambda_{1} \lambda_{2} \ldots \lambda_{n}\right)\left(\begin{array}{c}
\delta_{1 t} \\
\delta_{2 t} \\
\ldots \\
\delta_{n t}
\end{array}\right)=\left(\lambda_{1} \lambda_{2} \ldots \lambda_{n}\right)\left(\delta_{1 t} \delta_{2 t} \ldots \delta_{n t}\right)^{\prime}
$$

where $I_{t}$ - the current state of IP in the period of time $t$;

$\delta_{i t}=\left(\begin{array}{lll}\delta_{t t} & \delta_{2 t} & \ldots \delta_{n t}\end{array}\right)$ - vector of normalized values of indicators characterizing the state of IP in the period of time $t$;

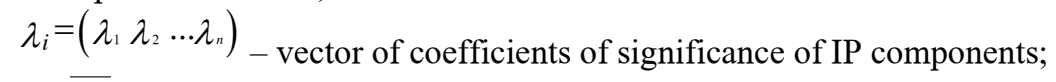

$i=\overline{1, n}$ - numbers of indicators characterizing the state of IP;

Obtaining an integral indicator of IP of a construction company makes it possible to manage the development of IP based on the data of its monitoring.

The relationship between the new and the current state of IP of the construction company in general can be represented as follows:

$$
\begin{aligned}
& \boldsymbol{I}_{t+1}=f\left(\boldsymbol{I}_{t} ; U_{j t} ; Z_{k t} ; t\right)=I_{t}+\Delta f\left(I_{t} ; U_{j t} ; Z_{k t} ; t\right)= \\
& =I_{t}+\sum_{i=1}^{n} \lambda_{i} * \Delta \delta_{i t}\left(I_{t} ; U_{j t} ; Z_{k t} ; t\right)
\end{aligned}
$$

where $I_{t+1}$ - new state of IP in the period of time $t+1$;

$U_{j t}=\left(u_{1 t} u_{2 t} \cdots u_{m t}\right)$-vector of developmental changes characterizing the targeted effects of change agents on IP in a period of time $t$;

$j=\overline{1, m}$ - numbers of developmental changes that characterize the impact of change agents on IP;

$Z_{k t}=\left(z_{1 t} z_{2 t} \cdots z_{p t}\right)$ - vector of development factors affecting the state of IP in the period of time $t$;

$k=\overline{1, p}$ - numbers of development factors characterizing the influence of the internal and external environment on the state of IP;

Model (3) describes the current state of IP at any moment of time on the interval [ $\mathrm{t} 0 ; \mathrm{T}]$, and together with equation (2) - the new state of IP in the same time interval.

$$
\left.\begin{array}{ll}
I_{t+1}=I_{t}+\sum_{i=1}^{n} \lambda_{i}^{*} \Delta \delta_{i t}\left(I_{i} ; U_{j i} ; Z_{k i} ; t\right), & (1) \\
\max \sum_{1}^{T} \lambda_{i}^{*} \delta_{i t} & \\
I_{t} \in A_{i}, & (2) \\
U_{j t} \in B_{i}, & (3) \\
Z_{k \in} \in C_{t}, & (4) \\
t \in[1 ; T], & (5)
\end{array}\right\}
$$

where $\Delta \delta_{i t}\left(I_{t} ; U_{j t} ; Z_{k t} ; t\right)$ - an increase in the normalized values of indicators characterizing the state of IP during a period of time under the influence of developmental changes and development factors; 
$A_{t}$ - range of admissible values of the vectors of IP of the construction company;

$B_{t}$ - range of admissible values of vectors of developmental changes;

$C_{t}$ - range of admissible values of vectors of development factors.

Equation (1) in model (3) represents the functional dependence of the new state of IP of the construction company on its current state, developmental changes, development factors, and time. In this model, expressions (2) - (4) are the mathematical formulation of constraints.

To implement the model for managing the development of IP of a construction company, an algorithm for managing the development of IP of a construction company was developed, consisting of five stages, in accordance with the management functions [8].

IP development management is based on its quantitative assessment, which allows tracking its actual state based on monitoring data, taking into account the influence of external factors.

Based on the complete system of indicators of potentials, an integral indicator of IP of a construction company is formed, which is schematically shown in Figure 1.

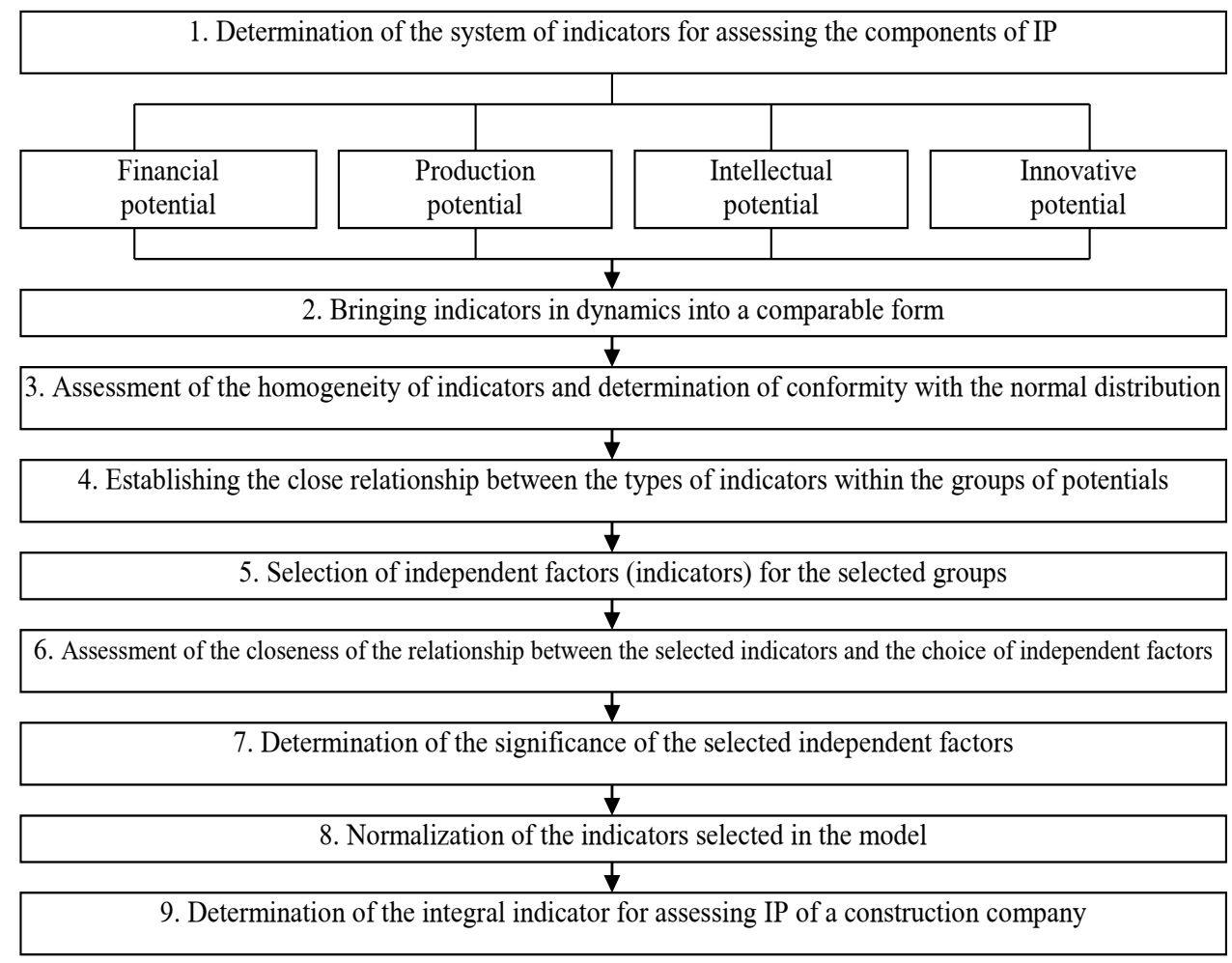

Fig.1. Formation of the integral indicator of IP of the construction company

However, the described method does not establish the principle of selecting one indicator from two correlated indicators. To solve this problem, we propose to be guided by: first, the principle of maximum variability accepted in statistics, according to which one should choose among the correlated variables with the highest coefficient of variation, i.e. $\arg \max \left(V\left(X_{i}\right)\right)$; second, the principle of economic expediency, choosing from two correlating indicators the one that is more important for assessing economic activity [9]. 


\section{Discussions}

The modified methodology for assessing the state of IP of a construction company allows us to give its quantitative characteristics, which is important from the point of view of assessing the influence of external factors. It was revealed that the most significant among such factors is the regional IP, i.e. it can be assumed that when assessing the influence of a region's IP on a company's IP, the influence of external factors will be taken into account. Assessing the impact and determining the tightness of the relationship between IP of the region and the company allows predicting the state of IP of a construction company for the period of implementation of its development strategy. This procedure is performed in the following sequence, in accordance with the provisions of the general theory of statistics: the trend of a region's IP is determined; the trend of a company's IP is determined; the reliability of setting trend parameters is assessed; the closeness of the connection between the indicators characterizing the state of IP of a company and a region is established; forecasting IP of a construction company for the period of implementation of its development strategy.

\section{Conclusion}

Investment activity is generally recognized as the basis for the effective functioning of any economic system, from an individual company to the national economy. The results of this study make it possible to expand the traditional essential boundaries of this type of activity in the direction of the possibility of implementing IP of companies in ICC. It is recommended to use production, financial, intellectual and innovative potentials as the main components of the potential of enterprises. The formation, state of development and efficiency of IP functioning are influenced by factors of the external and internal environment of varying degrees of controllability. The described methodology allows predicting the state for the period of implementation of the development strategy and provides an increase in the competitiveness and efficiency of the company as a whole.

\section{References}

1. P.A. Shokhov, L.G. Elkina, N.G. Kopeikina, Bulletin of USATU. Economics and national economy management 16.18 (53), 170-175 (2012)

2. E.S. Tskhovrebov, Vestnik MGSU 13.10, 1193-1203 (2018) DOI: 10.22227/19970935.2018.10.1193-1203

3. E.S. Zemskova Scientific journal NRU ITMO, Series: Economics and Environmental Management 4, 125-134 (2017) DOI: 10.17586 / 2310-1172-2017-10-4-125-134

4. Ya.S. Bakhova, E.N. Zakharova, Innovative Economy: Prospects for Development and Improvement 1(27) (2018)

5. E.F. Nikitskaya, A.E. Poikin, Internet journal "SCIENCE" 8.2 (2016) DOI: 10.15862 / 77EVN216

6. H. Millwater, J. Ocampo, N. Crosby, Engineering Fracture Mechanics 221 (2019) https://doi.org/10.1016/j.engfracmech.2019.106674

7. A. Aziz, M. Tajuddin, M. Adzman, M. Mohammed, M. Ramli, Energy 191 (2020) https://doi.org/10.1016/j.energy.2019.116591

8. R. Jean, D. Kim, E. Cavusgil, Journal of World Business 55(1) (2020) https://doi.org/10.1016/j.jwb.2019.101021

9. A. Dhoke, R. Sharma, T. Saha, Energy 194, 197-208 (2019) https://doi.org/10.1016/j.solener.2019.10.052 